\title{
Vultures and their People in India: Equity and Entanglement in a Time of Extinctions
}

\author{
Thom van Dooren
}

In conversations about vultures in India, people have often recounted to me having seen large numbers of these birds gathered along the banks of rivers consuming the dead bodies of cattle and other animals, including sometimes people, as they float by or wash up on the water's edge. When it meets a vulture's beak, it matters very little if this flesh, this meat, was once a human or some other kind of animal. In fact, numerous human societies throughout history-including current day Parsee communities in India and Buddhists in Tibet and elsewhereutilise exposure to vultures as the most appropriate way of 'taking care' of their dead (Subramanian; Schuz and Konig; van Dooren, Vulture). I am interested in the dynamics and practicalities of eating and being eaten in multispecies communities, but for the moment I would like to remain with the vultures on the banks on the Ganges and other rivers in India. Unlike most other scavengers, the vultures that my bird-watching friends saw are 'obligate' scavengers. This means that they do not opportunistically alternate between predation and scavenging (like their mammalian counterparts), but rather rely exclusively on finding animal carcasses. A vulture's whole body is oriented and adapted towards this method of food procurement and the lifestyle that accompanies it. In fact, Ruxton and Houston have even argued that it may have been in the development of the large body size and specialisations for efficient soaring flight that are so essential to being a successful avian scavenger, that vultures lost the flying accuracy, agility and manoeuvrability necessary to kill prey .

However it evolved, scavenging has offered a very successful way of life for vultures for a long time. While the fossil record is poor, it seems that in the 'old world' vultures stretch back over 20 million years. The genus Gyps, to which the vast majority of the vultures in India belong, probably arrived on the scene sometime in the last few million years (Rich; Houston, pers. comm.). But while scavenging has been evolutionarily successful for vultures, it is arguably not the most attractive way of getting a meal. It seems fair to say that vultures are a little bit gross. The Gyps species that occur in India live primarily in colonies, usually of 20-30 birds but sometimes in excess of 100; often roosting as close as possible to dumps or slaughterhouses, building their nests in tall trees or on cliff ledges, and lining them with wool, skin, dung and rubbish (Ferguson-Lees and Christie 422-8). While many animals scavenge food when it is available, few 
have taken to scavenging with the focus and vigour of the vultures. According to Dean Amadon, few of these other species 'will compete with vultures for badly decomposed remains' (ix). Inhabiting this environment of often less than 'fresh' food, it is no wonder that vultures possess a high level of resistance to various pathogens and diseases (Houston and Cooper). ${ }^{1}$ According to Amadon, 'it has been reported that vultures can, without ill effect, consume the viruses of such deadly pathogens as anthrax in such quantities as would fell an ox-or a whole herd of oxen' (ix).

But something is now poisoning vultures and threatening to cause their extinction in India and throughout the surrounding region. Over the past two decades vultures have been dying en masse, largely as a result of their being unintentionally poisoned by an anti-inflammatory drug called diclofenac that is given to cattle whose carcasses they eat. Diclofenac is used to treat any number of conditions in cattle, including lameness, mastitis, and difficult birthing (Cunningham; G. Swan et al., 'Removing' 0395). In vulture bodies, however, diclofenac causes painful swelling, inflammation, and eventually kidney failure and death. Today, it is thought that approximately $97 \%$ of the three main species of vulture in India are gone (Swan et al., 'Toxicity'; Prakash et al.). The discovery that vultures were disappearing entered the scientific literature through the work of Vibhu Prakash of the Bombay Natural History Society (BNHS) (Prakash). Since this time, the BNHS, in collaboration with the Royal Society for the Protection of Birds in the UK and the Zoological Society of London, has been conducting further research on the vulture decline. Together, these organisations have also established several conservation and breeding centres in India. The hope is that one day, when the threat of diclofenac is gone and there is a large enough captive population for it to be sustainable in the wild, the vultures might be able to be (re)released. Whether this will ever be able to happen, however, remains an open question.

1 While vultures will sometimes eat 'badly decomposed' food, they do prefer food that is relatively fresh (Houston, Condors). 


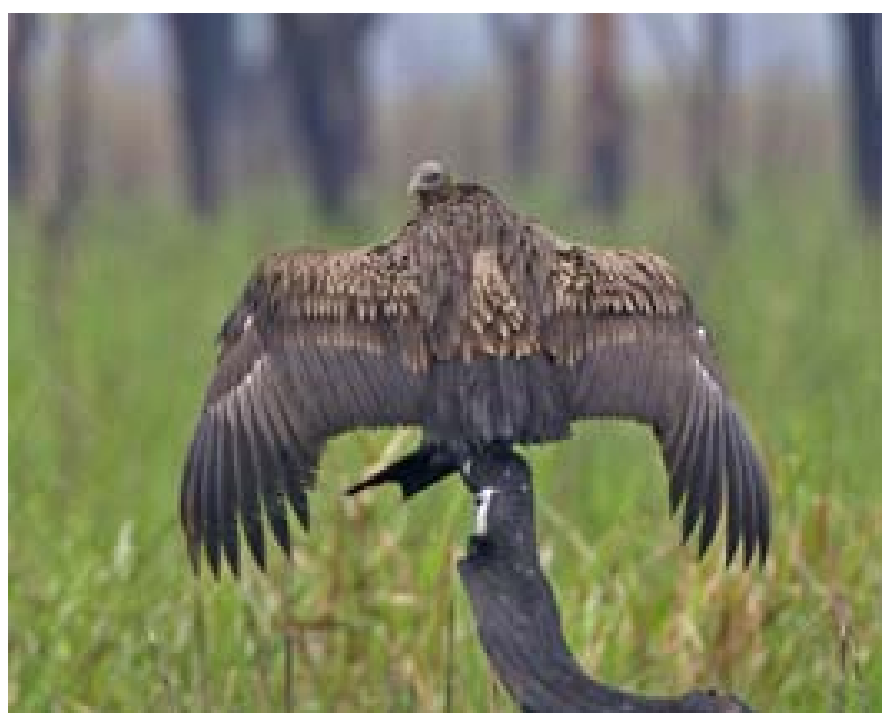

A critically endangered Indian white-backed vulture sunning (Gyps bengalensis).

Credit: Image by Lip Kee. Used under a CC Attribution-ShareAlike 2.0 Generic Licence.

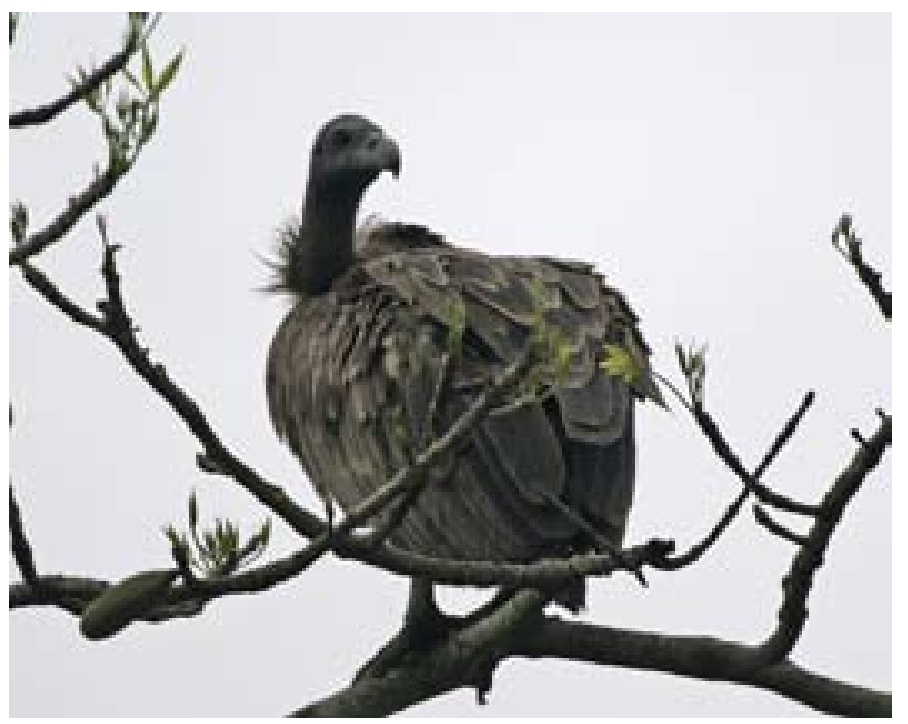

A critically endangered Indian white-backed vulture (Gyps bengalensis).

Credit: Image by Lip Kee. Used under a CC Attribution-ShareAlike 2.0 Generic Licence. 


\section{Between death and life (there is sometimes a vulture)}

It is a strange thing for an animal that is so closely associated with death, albeit usually the deaths of others, to be itself on the way to extinction. For me, as for many other people throughout history, and around the world, vultures seem to be a kind of liminal creature, inhabiting a space somehow strangely between life and death. Perhaps it is the way in which they seem to sense death, often arriving before it occurs (at least in part a skill acquired through good vision, the ability to search far and wide, and a kind of communicative observation of other vultures (Jackson et al.)); or maybe it is because they consume the dead and then soar high up into the sky (Houston, Condors 51). The deathly association and liminality that interests me, however, is the vulture's ability to 'twist' death back into life (Rose). My thinking here is situated within the kind of ecological context that Deborah Bird Rose and Val Plumwood have outlined. They remind us that death must not be thought about as a simple ending, but rather as something that is completely central to the ongoing life of multispecies communities, in which we are all ultimately food for one another (Plumwood, 'Tasteless').

In this context, vultures are at the heart of life and death's transformative potential. But instead of taking life to produce their nourishment, they consume only that which is already dead, pulling dead flesh back into processes of nourishment and growth. Alongside the insects, bacteria, fungi and others who also make their living breaking down the dead, I suspect that vultures have a special place in life's heart. I can't help but think here about Jean-Luc Nancy's beautiful injunction not to separate life from death: 'to isolate death from lifenot leaving each one intimately woven into the other, with each one intruding upon the other's core [coeur] - this is what one must never do' (Nancy 5). Vultures understand this intimate entanglement of life and death. I think that they would appreciate Nancy's sentiment, and be in wholehearted agreement with Georges Bataille when he noted that: 'life is a product of putrefaction, and it depends on both death and the dungheap' (Botting and Wilson 242).

Death, understood in this way, positions all organisms (including humans; a point that shouldn't have to be made, but unfortunately often does) as parts of a broader multispecies community. Possibilities for life and death, for everyone, get worked out inside these entangled processes of 'becoming-with' (Haraway, When Species Meet). That we can live at all, but also that we live in the ways in which we do, are the results of our specific situatedness in a more-thanhuman world. The biological and the social, the material and the discursive, alongside the living and the dead, are all mixed up in the formation of what come to be (and to count as) bodies, societies, religions, cultures and ecologies. The interactions of people, vultures, and others in India highlight some of 
these tangled processes of becoming, as well as the life and death stakes of the specific ways in which we are bound up with and exposed to others in a time of increasing environmental change.

\section{Entangled becomings}

Three main species of vulture make their homes in Asia, all three are of the genus Gyps: the oriental white-backed vulture ( $G$. bengalensis), the long-billed vulture (G. indicus) and the slender-billed vulture (G. tenuirostris). In the first half of the twentieth century, these species could be found in large numbers right across Southeast Asia, throughout the Indian subcontinent and into Pakistan. During the second half of that century, however, populations began to disappear throughout the eastern part of this range (Southeast Asia). The causes of this population decline are not known with certainty, but perhaps the most significant factor was the loss of reliable food sources. This loss likely occurred as a result of both the collapse of wild ungulate populations (through uncontrolled hunting) and changes in the husbandry of domestic animals. In addition, direct persecution of vultures by humans is thought to have impacted on their numbers, as did poisoning and habitat loss in some local areas (Pain et al. 661-2). While there are still some small remaining pockets of vultures in Cambodia and perhaps Laos and Vietnam, today Gyps vultures are otherwise considered to be extinct in Southeast Asia (Pain et al.).

In the face of these local extinctions, India represented one of the last strongholds of these species of vulture. Throughout most of the second half of the twentieth century, during this period of decline in Southeast Asia, life was good for vultures in India. In 1985, Indian populations were still so large that some speculated that the oriental white-backed vulture was 'possibly the most abundant large bird of prey in the world' (Pain et al. 661). In India there was nothing like the food shortage for vultures that occurred to the east; quite the opposite. While vultures in India certainly benefited from the fact that it is one of the most cattle rich countries in the world, from a vulture's perspective what makes India an ideal place to live is the fact that most of the cows there are not consumed by local people. Hindu reverence for cattle, alongside a more general ethos of ahimsa (or nonviolence towards all living things), has produced a unique and complex cultural and religious environment in which most Indians do not eat beef, and many are vegetarian (although Muslims and a growing number of Hindus do eat sheep, goats, other animals, and sometimes also beef (Robbins)). ${ }^{2}$

2 There are numerous other dimensions of the lives of cattle in India that cannot be understood as anything other than tragic. While almost all Indian states have bans on the slaughter of cattle, in many cases this has 
Cattle are predominantly used in India for ploughing, milking, and as general beasts of burden; and their dung is widely used as fuel and fertilizer (Robbins 226). When they die, cows are usually either taken to carcass dumps or left at the edge of villages, often after being skinned for leather (Singh). By and large, however, it is vultures that have been relied upon in India to 'take care' of an estimated five to ten million cow, camel and buffalo carcasses each year:

As many as 100 vultures may feed on a single cow carcass, stripping it clean in 30 minutes. Two thousand, 3,000, even 10,000 vultures swarmed the larger dumps in the early 1990s, the huge birds lapping at carcasses with their leathery tongues, thrusting their narrow heads neck-deep to reach internal organs, tussling over choice gobbets of meat. (McGrath)

In this context, vultures often lived quite closely with human populations. In urban and semi-urban environments, they found abundant food in carcass dumps, as well as in tanneries, slaughter yards, garbage dumps and bone mills (where they could pick the bones clean before they were crushed for use in fertilizers). But it was not just vultures that benefited from this association. These industries and local communities were provided with a free and efficient means of carcass disposal for the millions of cows that they kept but did not eat (as well as the waste products from numerous other kinds of animals). Consuming the dead is, of course, what vultures do. In taking up this role they help to stem the spread of contamination and disease (like anthrax, which is endemic in parts of India). When they live closely with people, especially in urban environments, they provide an extremely valuable 'service' to human communities (as will be discussed in more detail below). Understandably, this symbiotic exchange has provided an ideal situation for people and vultures to live side by side in India. Writing in 1983, Robert B. Grubh noted that: 'Where a regular food supply exists, it is a familiar sight to see 200 to 400 individuals sitting crowded on trees or on rooftops in the vicinity' (108).

This close entanglement of vultures and people in India is made all the more remarkable when contrasted with other places around the world where Gyps vultures have little association with human populations. In east Africa, for example, people understandably do not make meat available to vultures, but they also often shoot them if they start visiting towns and cities - especially the larger vulture species (Houston, pers. comm.; Houston, Condors). In addition to food availability, this contrast with Africa points to another important difference in the direct treatment of vultures by people. In India, vultures are far less likely to face the persecution that has afflicted them in so many other

simply meant that slaughter is carried out illegally — and thus in a completely unregulated manner — or cattle are subjected to long and crowded transportation to slaughterhouses in neighbouring states or countries (Singh). 
parts of the world - not just Africa and Southeast Asia, but also Europe and the Americas (Ferguson-Lees and Christie). It is most likely that significant cultural and religious dimensions of Hinduism and life in India account for at least part of this differential treatment; for example association with the mythical Hindu vulture king Jatayu (Baral et al. 151). There is most definitely also a more pragmatic dimension to this treatment, with vultures being widely understood to provide a very valuable service through the removal of dead flesh (Houston, pers. comm.; AFP).

But India is anything but a monolithic 'cultural landscape'. While it is beyond the scope of this paper to consider the diverse range of relationships with vultures around the country, outside of the majority Hindu culture, India's small Parsee community (centred in Mumbai) requires consideration in any discussion of vultures and their people in that country. For hundreds of years Parsees in India have laid their dead out to be consumed by vultures in dakhmas (or 'towers of silence'), believing that dead flesh pollutes fire, water and air-all of which are sacred to Ahura Mazda (Williams 158; Subramanian). In this context, humans provided an additional source of food for vultures, while the vultures provided an efficient and hygienic means of disposing of the dead. This Parsee practice provides a wonderfully rich acknowledgement and reminder of the place of human flesh in multispecies nourishment. Of course, Parsees and vultures don't need to be told that humans are edible. Some members of the Parsee community were so committed to the role of vultures in taking care of the dead that when vulture numbers at towers of silence started to decline, they proposed setting up a small captive population in an aviary to continue the process.

In this short section, I have offered only a handful of general examples from a diverse history of human/vulture interactions. What is clear, however, is that India has provided a somewhat unique environment for these birds. It is tempting to view this as a situation in which humans 'accommodated' vultures, making room for them within their communities. In reality, however, generations of Gyps vultures stretch back several million years into the deep past of the Indian continent. They were there well before human habitation; before humans even emerged as a species. It is likely that vultures evolved in close relationships with the wild migratory ungulate species like blackbuck, which were abundant until the arrival of people and domestic animals (Houston, 'Adaptive Radiation'), only later settling into growing 'human communities'. While it is certainly true that Indians have held open spaces for vultures in ways that other cultures around the world have not, it is also true that these people and their cultural and religious practices emerged and took shape in a land already inhabited by vultures. Together, vultures, people, cattle and others co-produced a unique environment in which food was made readily available for vultures, and in turn people were provided with a reliable and inexpensive means of disposing of 
the dead - this being particularly important for people who kept an abundance of cattle that they did not eat. In fact, one wonders how the cattle keeping practices that have emerged in India in company with Hinduism would have looked, or whether they would have even been possible, in the absence of these dedicated scavengers?

\section{Proximity and 'double death'}

But now these vultures are dying. In an age of diclofenac, both cattle and human bodies often no longer provide nourishment; vultures are no longer able to twist their deaths back into life. Instead, dead bodies are now poisoning vultures, producing more and more death. At the Parsee towers of silence the vulture decline seems to have begun in the 1970s, perhaps due to factors including urban growth in Bombay/Mumbai and an abundance of other food sources (Houston, pers. comm.), but perhaps also because diclofenac became available to people in the 1960s (for the treatment of inflammation), so the first birds to be affected would likely have been those that fed at the towers of silence. But, for vultures, the more recent widespread use of diclofenac for the treatment of cattle has been a far more serious problem. While human use of diclofenac might have been catastrophic for a captive population of vultures at a tower of silence- one of the reasons why some scientists withdrew their support for such a project - the use of the drug in cattle is far more significant for the overall collapse of vulture populations in India because cattle are a far more significant food source. As such it is vultures' role as consumers of cattle, rather than people, that will occupy the primary focus of my discussion.

Importantly, the use of diclofenac in the treatment of cattle is often driven by poverty, and the need to keep working animals even when they are old and sick.

If an animal is going sick, is going downhill, they want to get the most out of the animal. ... So you just pump pain killers and anti-inflammatories into it, to keep it going as long as possible ... and that's probably why such a high level of carcasses do have detectable levels of diclofenac. (Cunningham)

Here, poverty emerges in this paper explicitly for the first time, but it is a central theme in the unfolding of vulture/human relationships in India today, and as such a topic that I will return to below. In the emergence of vulture-toxic cattle, we encounter the flip side of the proximity and entanglement between people and vultures. While this close association has for a long time been mutually advantageous, it has now become a liability for everyone. Domesticated cattle once provided a great source of carrion for vultures, but this reliance on humans (more accurately on livestock that they keep) for food may now lead to vultures' extinction. In other parts of the world where diclofenac and other similarly 
toxic anti-inflammatories (Cuthbert et al.) are widely used, for example in east Africa, Gyps vultures have not been impacted by the drug like their Indian counterparts; largely because they haven't struck up a similar relationship with people, so their diet includes a greater proportion of the carcasses of wild animals (Cunningham).

Similarly, the entanglement and close proximity of people and vultures in India has become a liability for human communities. In their absence, it is has been made all too clear how important a role vultures played through the consumption of the dead, in creating an environment in which the unfolding and flourishing of so much other life could occur. Drawing on Rose's work, my position is that in India vultures and others are being drawn into a kind of 'double death'. For Rose, this concept marks a situation in which life's connectivities are unmade with disastrous consequences for a whole ecological community. In the story that Rose tells, dingoes are at the heart of this tragedy: having been baited with 1080 poison, they remain toxic even after death so that they poison those who feed on them. Here, death cannot be twisted back into life, and instead 'starts piling up corpses in the land of the living' (75). Rose explores the ramifications of this kind of death work among the Aboriginal people of Yarralin (for whom dingo is kin) and their more-than-human community.

The mass death of vultures occurring in India today is producing a related, but distinct, process of double death. In addition to the creation of an environment in which dead bodies, en masse, fail to nourish but rather poison, the absence of so many vultures has left a vast number of carcasses unscavenged-literally 'piling up corpses in the land of the living' (Rose 75). The disappearance of so many members of a species produces what ecologists call a 'functional extinction', one that will most likely be followed by an actual extinction in coming years. When vultures no longer inhabit the places and take up the relationships that they once did, the connectivities that make life possible in these places are unmade. As a result, a further 'doubling' of death has been set in motion in which all of those whose lives and wellbeing are entangled with vultures are drawn into a process of intensified suffering and death. Here, proximity and connectivity again become a liability, but in a way that highlights some of the inequalities of life, in which poorer nations, and in particular poorer communities within them, are more readily exposed to harm.

As previously noted, in consuming decomposing and sometimes diseaseladen bodies, vultures remove sources of potential contamination of soils and waterways, while also helping to prevent the spread of pathogenic organisms (Houston and Cooper). With digestive systems that routinely process 'foods' that even the most adventurous of others would not touch, vultures are very well positioned to clean up disease threats. For example, this ability may have been connected to the containment of anthrax in India. When an animal dies 
of anthrax, the spores of the disease can leach out into the soil where they can remain for decades, and can also be spread by wind and in the guts of other animals. In the past, vultures have tended to clean off all soft tissue within hours of an animal's death, before the anthrax bacteria have time to form spores and spread (Houston and Cooper; Cunningham). In their absence, there are fears that anthrax may become a more significant health problem, especially in the southern states where the disease remains endemic (Vijaikumar et al.). With seventy percent of India's population living in rural communities, and the majority dependent on livestock for their livelihoods, a huge number of people are potentially at risk of infection (Devinder and Karthikeyan). ${ }^{3}$

But anthrax is not the end of this story. In the absence of vultures, it is thought that available cattle carcasses in India might be making room for fast breeding scavengers like dogs and rats. While there are no accurate figures on street dog numbers across India, Markandya et al. have argued, drawing on Ministry of Agriculture census data, that it seems likely that dog numbers are increasing considerably as a direct result of vulture absence (Markandya et al. 198-9). While dogs do consume cattle carcasses, they don't do so with anywhere near the same speed or thoroughness that the vultures once did. As a result, they are not able to provide the same sort of containment of diseases like anthrax, and putrefying carcasses are increasingly left to contaminate waterways and the environment more generally.

In addition, however, large increases in dog numbers bring their own problems. According to a 2004 study conducted by the Association for the Prevention and Control of Rabies in India (and sponsored by the United Nations' World Heath Organization), approximately 17 million people are bitten by dogs in India each year, or roughly one person every two seconds (APCRI 44). Nationwide, the vast majority of the victims belong to 'poor' or 'low' income economic groups (75\%), and in rural areas this burden falls even more heavily on these poorer groups $(80.3 \%)$ (APCRI 25).

While dog attacks are themselves significant, in India dogs are also the primary vector for the transmission of rabies to humans, accounting for approximately $96 \%$ of all transmissions (APCRI 44). There are, therefore, fears that the incidence of rabies in India may be beginning to climb as a result of increased dog numbers. It is estimated that $60 \%$ of the world's rabies deaths already occur in India; approximately 25-30,000 per year, or one death every 30 minutes (APCRI 44). While there are vaccinations available for rabies, and these do seem to be reaching many people, total numbers of rabies deaths are only falling slightly-

3 Here, and in what follows, I have drawn on statistics in an effort to convey the immensity and the inequity of the problems developing in India in the absence of vultures. I am mindful, however, that numbers cannot really do this, and that statistics not only fail to capture suffering, they can also undermine the ethical demands that it issues (van Dooren, 'Pain'). Despite this fact, the numbers seem to tell a vital part of the story here. 
perhaps due to a large increase in the number of people being exposed to the disease in recent years (Menezes 564; Markandya et al. 199). In addition to the sheer number of people impacted, it should also not be forgotten that rabies is a horrific death. According to the British Medical Association's (BMA) guide to the disease: 'Once clinical symptoms of rabies appear, there is no known cure and the victim is virtually certain to die an agonizing and terrifying death' (BMA 13).

Like anthrax and dog attacks, rabies does not impact on all social groups evenly. The aforementioned 2004 study conducted by APCRI concluded that $87.6 \%$ of the people killed by rabies in India are from 'poor' or 'low' socioeconomic groups (APCRI 16). In addition, most of these victims were adult males, which the study noted might often bring additional economic hardship to families (APCRI 16). It should also be remembered that rabies does not only affect humans, but is also often transmitted to a variety of other animals and ultimately leads to painful deaths for many of them, including countless street dogs.

In addition to threats from environmental contamination and the spread of disease, the mass-death of vultures is also having economic impacts on some of India's poorest people. These people, often referred to simply as 'bone collectors', have in the past made a living gathering the dried bones of cattle and selling them to the fertilizer industry. In the absence of vultures, these bones are now often incompletely scavenged, requiring either extended periods of time before collection or for people to clean the bones themselves (Markandya et al. 195-6).

And so it is clear that while all humans are bound up in ecological relationships inside a multispecies world, we are not all entangled in the same ways. Those who are most directly dependent on vultures will suffer most and be lost first; in this case, rural and poor communities. But this is by no means an exceptional case. Drawing on case studies from around the world, the 2005 Millennium Ecosystem Assessment highlights the fact that ecosystem degradation and biodiversity loss will often impact disproportionately on poor and rural communities (these 'two groups' very often being one and the same) (MEA 3). These people tend to be directly dependent on their local environments for the provision of 'ecosystem services', such as the carcass disposal provided by vultures, or in other cases food and clean drinking water. When these environments are disturbed, these people lack the buffer that markets provide for the wealthy who are often simply able to purchase the good or service from further afield, or purchase a substitute. In addition, the MEA notes that 'ecosystem changes have played a significant role in the emergence or resurgence of several infectious diseases in humans' (MEA 27-8). Similarly, when this happens, these communities are more likely to lack the basic resources of life, as well as access to medical services, that would treat disease or prevent it from becoming established in their communities. In this context, vulnerability emerges, at least in part, as a feature 
of the specific ways in which we are entangled in our multispecies world; some are diffusely entangled, while others are bound up tightly in relationships with specific nonhumans and local ecologies (and thus highly exposed to changes or disturbances). ${ }^{4}$ In a time of extinctions, these interconnections produce a broader category of often disregarded lives - both human and nonhuman - that are being pulled into amplified patterns of loss and suffering.

\section{Conclusion}

Before their numbers began to decline so drastically, vulture species were very well adapted to their role as scavengers in Asia and the Indian subcontinent. As throughout the rest of the world, species of vultures in Asia developed feeding specialisations which effectively divided carcasses up; a situation that greatly helps to reduce competition when large numbers descend on a single carcass. Scientists often classify vulture species into three feeding groups, colourfully referred to as 'tearers', 'pullers' and 'peckers' (Konig). Put simply, 'tearer' species have powerful beaks for opening carcasses, while 'peckers' have more slender skulls, ideal for the more fiddly work of picking up small particles of food and separating meat from bone. Like all Gyps, the main species of vultures being poisoned in India are 'pullers'. These are perhaps the most stereotypical of vultures, reaching their long, agile, feather-free heads and necks deep into a carcass to pull out the viscera and soft flesh. Because these components of a carcass offer the richest source of food, Gyps make up by far the majority of the vulture population throughout the old world; usually around 90\%. In India, however, this number has traditionally been closer to 99\% (Houston, 'Adaptive Radiation' 136), perhaps largely because the need for 'tearer' species has been undermined by an ongoing entanglement with humans who 'open' carcasses when they remove the skin for leather.

The dominance of Gyps vultures in India has only added to the tragedy of their extinction. Physiological responses of bird species to anti-inflammatory drugs like diclofenac are generally not well understood. In recent years, however, there has been some suggestion that non-Gyps species of vulture and other scavenging birds in India may not be impacted upon by the drug in the same lethal way (Meteyer et al. 714). ${ }^{5}$ If this is the case, other species of vulture no longer found in large numbers in India might, therefore, have survived in the presence of diclofenac. But for the longest time now, India has been a land of Gyps vultures, knotted together in so many different ways with people inside larger multispecies communities. These processes of knotting, alongside the often painful unknotting that is occurring today, highlight processes of entangled

4 For a very different discussion of environmental justice and direct relationships with places/ecologies, see Plumwood, 'Shadow Places'.

5 But see Cuthbert et al. 
becoming that cut across human/nonhuman and nature/culture binaries to produce a rich multispecies world. In addition, the multispecies community I have described is one comprised of both the living and the dead. The extinction of vultures points to the necessity of a concept and a practice of community that draws in the dead; in which what happens to the dead, how they (and we) are 'taken care' of (and by whom), what contributions they are able to make (and to whom), are all deeply consequential for the health and continuity of others. Dead vultures, dead cattle, dead people, all matter in the interactions that produce possibilities of and for life and death. And so, it is not just the living that make, and sometimes unmake, flourishing communities.

But as these relationships have been unravelled in this time of extinctions, those people most closely dependent on vultures have been the first drawn into patterns of intensified suffering and death; another form of what Rose has called 'double death' . In this context, it does not seem to be enough to say that 'we are all bound up in relationships of dependence in a multispecies world'. Clearly, we need to understand precisely how different communities (of humans and nonhumans) are entangled, and how these entanglements are implicated in the production of both extinctions and their accompanying patterns of amplified death. This kind of information requires case specific study and an approach to communities that moves beyond absolute distinctions between humans and nonhumans, the living and the dead.

Equally, it requires an approach to the world in which we 'cast our lot for some ways of life [and death] and not others' (Haraway, Modest_Witness 36). One might argue, for example, that in addition to a doubling of death in some domains, the demise of vultures has actually produced the possibility for new life in other contexts. While vultures may no longer be around to consume carcasses, this tragic situation has made room for the growth of populations of other animals, like dogs. While many of these dogs live in awful conditions and die painful deaths from rabies and other diseases, their mere presence highlights the fact that food is rarely ever wasted in any absolute sense; a situation that is made clear if we are prepared to shift our focus and acknowledge the broader 'company' (Haraway, Companion Species) of species at the table in any, even moderately healthy, ecosystem. Inside rich histories of entangled becoming - without the aid of simplistic ideals like 'wilderness', 'the natural' or 'ecosystemic balance' - it is ultimately impossible to reach simple, black-andwhite prescriptions about how ecologies 'should be'. And so we are required to make a stand for some possible worlds and not others, we are required to begin to take responsibility for the ways in which we help to tie and retie our knotted multispecies worlds (Barad 353-96). How to live well within the always unequal patterns of amplified loss and suffering that are produced here is an issue that 
can only take on increasing significance as we move ever more deeply into the Earth's sixth great extinction event and a period of growing environmental and climatic change.

Thom van Dooren is currently Chancellor's Postdoctoral Research Fellow at the University of Technology, Sydney. From July 2011 he will be a Lecturer in Interdisciplinary Environmental Studies at the University of New South Wales. He is the author of Vulture (forthcoming 2011), and is currently completing work on another book of bird stories focused on themes of loss, death and extinction.

\section{Works Cited}

AFP. 'Nepali Vulture "Restaurant" Aims to Revive Decimated Population.' AFP, 29 October 2007. <http://afp.google.com/article/ ALeqM5hXfBY76myTDIuT9ACEa0mIBcoRVw> Accessed 10 Jul. 2009.

Amadon, Dean. 'Foreword.' Vulture Biology and Management. Ed. Sanford R. Wilbur and Jerome A. Jackson. Berkeley: U of California P, 1983. ix-xi.

APCRI. Assessing the Burden of Rabies in India-WHO Sponsored National Multi-Centric Rabies Survey 2003. Bangalore: Association for the Prevention and Control of Rabies in India, 2004.

Barad, Karen. Meeting the Universe Halfway: Quantum Physics and the Entanglement of Matter and Meaning. Durham: Duke UP, 2007.

Baral, Nabin, et al. 'Conservation Implications of Contingent Valuation of Critically Endangered White-Rumped Vulture Gypsbengalensis in South Asia.' International Journal of Biodiversity Science and Management 3 (2007): $145-56$.

BMA. The BMA Guide to Rabies. Oxford: Radcliffe Medical Press, on behalf of the British Medical Association, 1995.

Botting, Fred, and Scott Wilson, eds. The Bataille Reader. Oxford: Blackwell, 1997.

Cunningham, Andrew. Interview conducted at the Institute of Zoology, Zoological Society of London, 11 September 2008.

Cuthbert, Richard, et al. 'NSAIDS and Scavenging Birds: Potential Impacts Beyond Asia's Critically Endangered Vultures.' Biology Letters 3 (2007): 91-4. 
Devinder, M. Thappa, and Kaliaperumal Karthikeyan. 'Anthrax: An Overview within the Indian Subcontinent.' International Journal of Dermatology 40 (2001): 216-22.

Ferguson-Lees, James, and David A. Christie. Raptors of the World. New York: Houghton Mifflin Harcourt, 2001.

Grubh, Robert B. 'The Status of Vultures in the Indian Subcontinent.' Vulture Biology and Management. Ed. Sanford R. Wilbur and Andrew L. Jackson. Berkeley: U of California P, 1983. 107-12.

Haraway, Donna. The Companion Species Manifesto: Dogs, People, and Significant Otherness. Chicago: Prickly Paradigm Press, 2003.

-. Modest_Witness@Second_Millenium.Femaleman $\left(\right.$ C_Meets_Oncomouse ${ }^{\mathrm{TM}}$ : Feminism and Technoscience. New York: Routledge, 1997.

—. When Species Meet. Minneapolis: U of Minnesota P, 2008.

Houston, David C., and J.E. Cooper. 'The Digestive Tract of the Whiteback Griffon Vulture and Its Role in Disease Transmission among Wild Ungulates.' Journal of Wildlife Diseases 11 (1975): 306-13.

Houston, David C. 'The Adaptive Radiation of the Griffon Vultures.' Vulture Biology and Management. Ed. Sanford R. Wilbur and Andrew L. Jackson. Berkeley: U of California P, 1983. 135-52.

—. Condors and Vultures. Stillwater, MN: Voyageur Press, 2001.

—. Personal communication. Email sent 15 June 2009.

Jackson, Andrew L., Graeme D. Ruxton, and David C. Houston. 'The Effect of Social Facilitation on Foraging Success in Vultures: A Modelling Study.' Biology Letters 4 (2008): 311-13.

Konig, Claus. 'Interspecific and Intraspecific Competition for Food among Old World Vultures.' Vulture Biology and Management. Ed. Sanford R. Wilbur and Andrew L. Jackson. Berkeley: U of California P, 1983. 153-71.

Markandya, Anil, et al. 'Counting the Cost of Vulture Decline: An Appraisal of the Human Health and Other Benefits of Vultures in India.' Ecological Economics 67 (2008): 194-204.

McGrath, Susan. 'The Vanishing.' Smithsonian Magazine, February 2007.

MEA. Millennium Ecosystem Assessment: Current State \& Trends Assessment (Volume 1). Washington D.C.: World Resources Institute, 2005. 
Menezes, Rozario. 'Rabies in India.' Canadian Medical Association Journal 178.5 (2008): 564-6.

Meteyer, Carol Uphoff, et al. 'Pathology and Proposed Pathophysiology of Diclofenac Poisoning in Free-Living and Experimentally Exposed Oriental White-Backed Vultures (Gyps bengalensis).' Journal of Wildlife Diseases 41.4 (2005): 707-16.

Nancy, Jean-Luc. 'L'intrus.' The New Centennial Review 2.3 (2002): 1-14.

Pain, Deborah J., et al. 'Causes and Effects of Temporospatial Declines of Gyps Vultures in Asia.' Conservation Biology 17.3 (2003): 661-71.

Plumwood, Val. 'Shadow Places and the Politics of Dwelling.' Australian Humanities Review 44 (2008): 139-150.

—. 'Tasteless: Towards a Food-Based Approach to Death.' Environmental Values 17.3 (2008): 323-330.

Prakash, Vibhu. 'Status of Vultures in Keoladeo National Park, Bharatpur, Rajasthan, with Special Reference to Population Crash in Gyps Species.' Journal of the Bombay Natural History Society 96 (1999): 365-78.

-, et al. 'Recent Changes in Populations of Resident Gyps Vultures in India.' Journal of the Bombay Natural History Society 104.2 (2007): 129-35.

Rich, Pat V. 'The Fossil Record of the Vultures: A World Perspective.' Vulture Biology and Management. Ed. Sanford R. Wilbur and Andrew L. Jackson. Berkeley: U of California P, 1983. 3-25.

Robbins, Paul. 'Shrines and Butchers: Animals as Deities, Capital, and Meat in Contemporary North India.' Animal Geographies: Place, Politics, and Identity in the Nature-Culture Borderlands. Ed. Jennifer Wolch and Jody Emel. London: Verso, 1998. 218-39.

Rose, Deborah Bird. 'What If the Angel of History Were a Dog?' Cultural Studies Review 12.1 (2006): 67-78.

Ruxton, Graeme D., and David C. Houston. 'Obligate Vertebrate Scavengers Must Be Large Soaring Fliers.' Journal of Theoretical Biology 228 (2004): 431-36.

Schuz, Ernst, and Claus Konig. 'Old World Vultures and Man.' Vulture Biology and Management. Ed. Sanford R. Wilbur and Andrew L. Jackson. Berkeley: U of California P, 1983. 461-69. 
Singh, Jyotsna. 'India Targets Cow Slaughter.' BBC News, 11 August 2003. <http://news.bbc.co.uk/2/hi/south_asia/2945020.stm> Accessed 05 May 2009.

Subramanian, Meera. 'Towering Silence.' Search: Science, Religion, Culture, May/ June 2008.

Swan, Gerry E. 'Toxicity of Diclofenac to Gyps Vultures.' Biology Letters 2 (2006): 279-82.

- et al. 'Removing the Threat of Diclofenac to Critically Endangered Asian Vultures.' PLoS Biology 4.3 (2006): 0395-402.

van Dooren, Thom. 'Pain of Extinction: The Death of a Vulture.' Cultural Studies Review 16.2 (2010): 271-289.

-. Vulture. London: Reaktion Books, forthcoming 2011.

Vijaikumar, M., M. Thappa Devinder and K. Karthikeyan. 'Cutaneous Anthrax: An Endemic Outbreak in South India.' Journal of Tropical Pediatrics 48.4 (2002): 225-6.

Williams, Alan. 'Zoroastrianism and the Body.' Religion and the Body. Ed. Sarah Coakley. Cambridge: Cambridge UP, 1997. 